\title{
Eryk Cichocki
}

Uniwersytet Wrocławski

DOI 10.19195/1642-5782.15(25).9

\section{Uchodźcy w opowiadaniach uczniowskich}

W ostatnim czasie tak zwany kryzys uchodźczy wywołuje wśród Europejczyków skrajne emocje. Kryzys ten umownie rozpoczął się w 2015 r. $^{1}$ i polega na gwałtownym wzroście docierających do Europy migrantów. Napływający ludzie tworzą niejednorodną grupę, ponieważ wśród przybyszów znajdują się zarówno uchodźcy ${ }^{2}$, jak i imigranci ekonomiczni. Jak pokazują badania statystyczne, stosunek Polaków do uchodźców (i co za tym idzie - do przyjmowania ich) znacząco się zmienił po zamachach w Paryżu z listopada 2015 r. i do dziś pozostaje nieprzychylny ${ }^{3}$. Tym samym tematyka uchodźcza stała się silniej akcentowana w wielu badaniach socjologicznych, antropologicznych, filozoficznych, językoznawczych czy literaturoznawczych. Mimo to w dydaktyce polonistycznej wciąż brakuje pogłębionej refleksji nad tym trudnym tematem ${ }^{4}$.

W niniejszym artykule przedstawię wizerunek uchodźców ukazany w wypracowaniach uczniów klasy szóstej jednej z wrocławskich szkół podstawowych. Służyć temu będzie analiza dwudziestu ośmiu opowiadań powstałych po piątym etapie eksperymentu naturalnego dydaktycznego poświęconego inności i obcości.

${ }^{1}$ Przyjęcie roku 2015 za początek kryzysu migracyjnego jest umowne i wynika ze złożenia rekordowej liczby $(1,2 \mathrm{mln})$ wniosków o azyl w państwach Unii Europejskiej. Według danych UNHCR największą grupę imigrantów tworzyli Syryjczycy, Afgańczycy, Irakijczycy. Por. http:// uchodzcy.info/infos/stosunek-polakow-do-uchodzcow/ [dostęp: 13.07.2017].

2 Przyjmuję definicję uchodźcy zawartą w konwencji dotyczącej statusu uchodźców, https:// amnesty.org.pl/wp-content/uploads/2016/04/Konwencja_Dotyczaca_Uchodzcow.pdf [dostęp: 13.07.2017].

${ }^{3}$ CBOS, Stosunek Polaków do przyjmowania uchodźców, Komunikat z Badań 2017, nr 1.

${ }^{4}$ Badania dydaktyki ogólnej i polonistycznej skupiają się wyłącznie na konieczności poznania uchodźców, rzadziej sprawdzają uczniowską wiedzę i wyobrażenia na ich temat. (Por. M. Bohosiewicz et al., Imigranci w mojej klasie, Warszawa 2011; M. Czerniejewski et al., Uchodźcy. Materiat pomocniczy dla prowadzacych zajęcia na temat uchodźców, Poznań 2011; Zrozumieć innych, czyli jak uczyć o uchodźcach, red. K. Koszewska, Warszawa 2011). 
Skupię się wyłącznie na zakresie tematycznym analizowanych prac. Ze względów formalnych i teleologicznych niniejsze studium ma charakter empiryczny. Artykuł składa się z trzech części: wstępu wyjaśniającego charakter przeprowadzanego eksperymentu, zasygnalizowaniu literatury przedmiotu dotyczącej zagadnienia inności i obcości oraz analizy wypracowań szkolnych.

\section{Kilka uwag wstępnych}

Wypracowania uczniów powstały w ramach eksperymentu naturalnego dydaktycznego ${ }^{5}$ na temat inności i obcości, trwającego od marca do czerwca 2016 r. w klasie szóstej jednej z wrocławskich szkół podstawowych. Badaną grupę stanowili dwunasto- i trzynastolatkowie. Zmienne niezależne eksperymentu zakładały: wzrost zasobu słownictwa ogólnego, słownictwa dotyczącego Innego, Obcego, wzrost umiejętności tworzenia form wypowiedzi przewidzianych po drugim etapie edukacyjnym oraz uwrażliwienie uczniów na mechanizmy wykluczające Innych i Obcych.

Badanie wstępne eksperymentu określiło, co uczniowie rozumieją pod pojęciami „Inny”, „Obcy”. Uchodźcy zostali zaliczeni przez nich do szerszej grupy „wędrowców, uciekinierów i imigrantów”. Im właśnie został poświęcony piąty etap eksperymentu, który zakończył się napisaniem opowiadania z dialogiem. Za Stownikiem terminów literackich rozumiem opowiadanie jako:

gatunek epicki; utwór prozaiczny niewielkich rozmiarów o prostej, zazwyczaj jednowątkowej fabule, bliski noweli ze względu na wielość i ciążenie przebiegu zdarzeniowego ku wyraźnie akcentowanemu zakończeniu, ale różniący się od niej daleko posuniętą swobodą kompozycyjną, epizodycznością fabuły, obecnością dygresji, partii opisowych i refleksyjnych, a często także eksponowaniem osoby narratora i okoliczności towarzyszących narracji ${ }^{7}$.

Przyjmuję też podział opowiadań szkolnych zaproponowany przez Marię Nagajową ${ }^{8}$ :

${ }^{5}$ Znaczącą rolę wśród badań dydaktycznych odgrywa eksperyment. Jego zasady, cele i poszczególne etapy opisali m.in. M. Łobocki, Metodologia badań pedagogicznych, Warszawa 1982; T. Pilch, T. Bauman, A. Radźko, Zasady badań pedagogicznych, Warszawa 1995; W. Zaczyński, Praca badawcza nauczyciela, Warszawa 1995; C. Kupisiewicz, Podstawy dydaktyki, Warszawa 1982. Wśród językoznawców wykorzystujących tę metodę ważną rolę odegrała M. Dudzik, która na wrocławskiej polonistyce stała się propagatorem, zasłużonym praktykiem i teoretykiem eksperymentu naturalnego dydaktycznego (zob. artykuły M. Dudzik w tomie 1 i 3 „Kształcenia Językowego w Szkole").

${ }^{6}$ Wstępny etap eksperymentu dowiódł, że uczniowie nie rozróżniają podstawowych pojęć związanych z migrantami. Braki te szóstoklasiści uzupełnili podczas piątego etapu eksperymentu. s. 329 .

7 Opowiadanie, [hasło w:] Stownik terminów literackich, red. J. Sławiński, Wrocław 1988,

${ }^{8}$ M. Nagajowa, ABC metodyki nauczania języka polskiego dla początkujacych nauczycieli, Warszawa 1995, s. 138. 
a) opowiadanie odtwórcze, tj. opowiadanie własnymi słowami o wydarzeniach przeczytanych lub usłyszanych $[\ldots]$;

b) opowiadanie twórcze: a) na podstawie lektury; polega ono na wymyślaniu zdarzeń związanych z postacią literacką, uzupełniających fabułę tekstu literackiego [...]; b) oparte na doświadczeniach ucznia, czyli przedstawiające wydarzenia, których był on uczestnikiem albo świadkiem [...]; c) wymyślone przez ucznia (fikcyjne) [...];

c) opowiadanie z dialogiem, czyli opowiadanie z wkomponowaną rozmową postaci - bohaterów opowiadania.

Wypracowania uczniowskie dostarczają ciekawego materiału do wielu badań. Akcentują podmiotowość piszących. Są zapisem indywidualnych sposobów myślenia i postrzegania świata, przy założeniu, że uczniowie pracują samodzielnie.

Warto podkreślić specyfikę opowiadań uczniowskich, które Maria Nagajowa i Halina Wiśniewska zaliczają do szerszej kategorii — wypracowań szkolnych? ${ }^{9}$. W dydaktyce polonistycznej wypracowania są efektem działań dydaktycznych, na które składają się zdobywanie wiedzy, utrwalanie i doskonalenie umiejętności. Służą także diagnozowaniu i ocenianiu osiągnięć edukacyjnych. Wypracowania są więc konsekwencją uczestniczenia ucznia $\mathrm{w}$ dyskursie szkolnym ${ }^{10}$, w którym prace mogą powstawać zarówno ze szczerych i ambitnych intencji młodych autorów, jak i z przymusu i obowiązku ${ }^{11}$. Część poddanych analizie opowiadań pisana była przez uczniów w domu, część w szkole. Istnieje oczywiście podejrzenie, że zadanie domowe niektórych uczniów było czymś inspirowane bądź też ktoś po prostu pomógł w jego wykonaniu. Jednak chcę podkreślić, że wypracowania w tej klasie zazwyczaj cechował wysoki poziom kompetencji tekstotwórczej ${ }^{12}$.

\section{Uchodźcy - Inni, Obcy}

Tematyka uchodźców wpisuje się w szersze zagadnienie — Innego i Obcego. Do kanonicznych prac traktujących o nie-Swoich należą pisma Emmanuela Le-

${ }^{9}$ Dla M. Nagajowej wypracowanie szkolne to: „każda pisemna forma dłuższej wypowiedzi. Dzielą się na: a) wypracowania domowe, pisane jako praca domowa zadana na lekcji; b) wypracowania klasowe pisane w klasie" (ibidem, s. 253). H. Wiśniewska zaś, opisując specyfikę wypracowań uczniowskich, stwierdza: „Jak widzimy, niektóre z tych form [opowiadanie, opis, charakterystyka, rozprawka, sprawozdanie, streszczenie] to twory »sztuczne«, czysto szkolne, bo ćwiczeniowe (np. opisy, charakterystyki postaci), ale niektóre przygotowują do pisania tekstów naukowych (np. rozprawki), publicystycznych (np. reportaże) i paraliterackich (np. opowiadania)" (eadem, Łatwa i trudna kompozycja wypracowań uczniowskich, [w:] Wokól edukacji polonistycznej w szkole. Teoria i praktyka, red. M. Karwatowska, L. Tymiakin, Lublin 2016, s. 260).

${ }^{10} \mathrm{O}$ dyskursach edukacyjnym i szkolnym pisali m.in. J. Labocha, Dyskurs jako proces przekazywania wiedzy, [w:] Dyskurs edukacyjny, red. T. Rittel, Kraków 1996; A. Skudrzykowa, J. Warchala, Dyskurs edukacyjny a kompetencja interakcyjna, „Studia Pragmalingwistyczne” 2002, nr 3.

${ }^{11}$ Por. E. Nowak, Stworzyć tekst. Uczniowska kompetencja tekstotwórcza w edukacji polonistycznej, Kraków 2014, s. 39-40.

12 Wniosek ten formułuję jako nauczyciel polonista pracujący w eksperymentalnej klasie w latach 2013-2016. 
vinasa $^{13}$ i Bernharda Waldenfelsa ${ }^{14}$. W literaturze przedmiotu funkcjonuje wiele definicji, które próbują uregulować zakres treściowy trudnych do jednoznacznego i kategorycznego rozróżnienia pojęć Innego i Obcego ${ }^{15}$.

Ewa Zamojska wyjaśnia powody takiego stanu rzeczy, wskazując na długoletnią tradycję rozumienia obcości zawartą w słownikach antropologii kulturowej. Podkreśla, że w wyniku tego często Inny i Obcy to pojęcia traktowane synonimicznie, a ich rozdzielenie przypisuje się tradycji określonej dyscypliny naukowej, z której wyrasta badacz. Tradycyjnie Obcemu przypisuje się konkretność, dostrzegalny jest dystans zarówno terytorialny, jak i emocjonalny. Dystans ten wynika z różnic kulturowych: religijnych, językowych, etnicznych itp. ${ }^{16}$

Współczesne badania nad innością i obcością przybrały charakter interdyscyplinarny. Zajmują się nimi nie tylko antropologowie czy etnografowie, lecz także ekonomiści, prawnicy, socjologowie, filozofowie czy literaci. W badaniu Innego i Obcego jest coś z numinosum, co oznacza, że: „Obcy/Inny jest poniekąd i groźny, i twórczy (dlatego jednocześnie może budzić podziw i przerażenie). [...] Numinosum to tajemnicza, budząca lęk, lecz i pociągająca siła"17.

Literatura pokazuje wiele postaci będących Obcymi dla świata, nazwijmy go roboczo, „normatywnego”. Pojawiają się Romowie wśród nie-Romów, Żydzi wśród nie-Żydów, muzułmanie wśród katolików, zdrowi wśród chorych, żywi wśród umarłych itp. Obcy przełamują porządek świata przedstawionego, prowokują bohaterów literackich do takich czy innych czynów, są obiektami zaciekawienia, ale także agresji i nienawiści. Moralność wobec Obcych jest wybiórcza, przestają działać powszechnie przyjęte kategorie interpretacji świata; Obcy są ludźmi, przeciwko którym występuje większość, chcąca narzucić jedyną i sobie prawdziwą egzemplifikację rzeczywistości. Hanna Gosk podsumowuje: „Opowieść Innego/Obcego, jeśli dać mu głos, to opowieść o nas samych w sytuacji utraty gorsetów i uniformów, które od tej chwili będą podlegać modyfikacji”"18.

${ }^{13}$ E. Levinas, Etyka i nieskończony, przeł. B. Opolska-Kokoszka, Kraków 1994 („Teksty Filozoficzne"); idem, Trudna wolność, przeł. A. Kuryś, Gdynia 1991.

${ }^{14}$ B. Waldenfels, Topografia obcego. Studia z fenomenologii obcego, przeł. J. Sidorek, Warszawa 2002; idem, Podstawowe motywy fenomenologii obcego, przeł. J. Sidorek, Warszawa 2009.

${ }^{15}$ Zob. M. Jacyno, Iluzje codzienności. O teorii socjologicznej Pierre'a Bourdieu, Warszawa 1997; P. Celiczko, P. Kuciński, Literackie portrety innego, t. 3, Warszawa 2008; M. Dąbrowski, Swój/Obcy/Inny. Z problemów interferencji i komunikacji międzykulturowej, Izabelin 2001; Inny obcy wróg. Swoi i obcy w świadomości młodzieży szkolnej i studenckiej, red. E. Nowicka, J. Nawrocki, Warszawa 1996.

16 Por. E. Zamojska, Inny jako Obcy. Imigranci w polskim dyskursie publicznym i edukacyjnym, ,Studia Edukacyjne” 2013, nr 28, s. 191.

${ }^{17}$ H. Gosk, O czym opowiada Inny/Obcy, „Horyzonty Polonistyki” 2006, nr 6, s. 11-12.

18 Ibidem. 


\section{Analiza opowiadań uczniowskich}

Uczniowie otrzymali polecenie: wyobraź sobie, że stoisz na przystanku tramwajowym, gdy nagle podchodzi do ciebie nieznany mężczyzna/kobieta i zaczyna swoją wypowiedź od słów: „Byłem uciekinierem...”. Napisz opowiadanie, w którym zawrzesz dialog między tobą a napotkaną osobą.

Lektura wypracowań pozwoliła wyodrębnić następujące kryteria analizy:

a) kim jest uciekinier?

b) jaki jest powód uchodźstwa?

c) co tracą uchodźcy?

d) jakimi cechami charakteryzują się uchodźcy?

e) jakie trudności napotykają uchodźcy?

f) jakie propozycje pomocy słyszy uchodźca?

g) jak ułożyło się uchodźcom życie w Polsce?

Dalej przedstawiam wyniki badania i najważniejsze wnioski.

Ad a) Kim jest uciekinier?

- Syryjczykiem ze swoją rodziną, mieszkańcem Aleppo,

— nie zdradza, kim jest,

— chrześcijaninem,

- ciemnoskórym mieszkańcem krajów islamskich,

— byłym żołnierzem z Afganistanu,

- Kazachem,

- uciekinierem $\mathrm{z}$ domu,

- Rosjaninem o chińskich korzeniach w czasie rewolucji październikowej,

- Ukrainką.

W analizowanych pracach uczniowskich „uciekinierami” są najczęściej Syryjczycy, samotni lub z rodzinami. Po Syryjczykach najliczniej w opowiadaniach występowali bohaterowie, którzy nie zdradzali, skąd są. Trzecie miejsce zajmują uciekający przed prześladowaniami chrześcijanie. Po nich najliczniejszą grupę stanowią ciemnoskórzy mieszkańcy krajów islamskich oraz uciekinierzy przed wojną.

Niektórzy uczniowie dostrzegają, że uchodźcami są nie tylko mieszkańcy Syrii (i wyznawcy islamu), lecz także osoby pochodzące z krajów europejskich (Ukraińcy). W badanych pracach dostrzec można, że miejsce pochodzenia, wyznawana wiara, ukryte bądź jawne intencje obcokrajowców, chęć pokoju stają się powodami odróżniającymi Swojego od Obcego.

W analizowanych opowiadaniach nazywanie uchodźcą hiszpańskiego turystę lub emigranta z Grecji świadczy o nieodróżnianiu przez autorów tych opowiadań podstawowych pojęć związanych z tematyką migracyjną. 
Ad b) Jaki jest powód uchodźstwa?

\begin{tabular}{|l|l|}
\hline \multicolumn{1}{|c|}{ Powód uchodźstwa } & \multicolumn{1}{c|}{ Fragment opowiadania, numer pracy } \\
\hline $\begin{array}{l}\text { Krzywda psychiczna i fizyczna, } \\
\text { atak terrorystów }\end{array}$ & $\begin{array}{l}\text { Im starsza byłam, tym lepiej zdawałam sobie sprawę z róż- } \\
\text { nic pomiędzy prawami kobiet i mężczyzn. W końcu posta- } \\
\text { nowiłam walczyć o równouprawnienie. Przyłączyłam się do } \\
\text { grupy walczącej o to samo. Na początku nie robiłam nic, } \\
\text { zadowolona, że zrobiłam coś dla tej sprawy. Później zdałam } \\
\text { sobie sprawę, że moje wstąpienie do grupy nic nie pomogło } \\
\text { i niczego nie zmieniło. Wtedy zaczęłam działać bardzo in- } \\
\text { tensywnie. Nie mogło się to dla mnie dobrze skończyć. Za- } \\
\text { mknięto mnie w więzieniu dla kobiet na dziesięć lat - ciem- } \\
\text { nowłosa opowiedziała o tym z niemałym smutkiem. (20) }\end{array}$ \\
\hline $\begin{array}{l}\text { Prześladowanie za wiarę, chrze- } \\
\text { ścijan }\end{array}$ & $\begin{array}{l}\text { Pewnego dnia usłyszałem strzały i krzyki. Wyjrzałem przez } \\
\text { okno i ujrzałam dym oraz ogień, potem przyjechały ciężarów- } \\
\text { ki samochody z czarnymi flagami. Kazali mi udowodnić swo- } \\
\text { ją wiarę, bo inaczej mnie zabiją. Powiedziałem, że muszę się } \\
\text { przygotować. Wyskoczyłem przez okno i biegłem. (7) }\end{array}$ \\
\hline Wojny & $\begin{array}{l}\text { Gospodarka w moim kraju nie jest w najlepszym stanie. Mój } \\
\text { syn mieszka niedaleko stąd i to dzięki niemu mogłem się } \\
\text { wyprowadzić. Nie sądzę, że „wyprowadzić” to dobre słowo. } \\
\text { Tak naprawdę była to ucieczka. Ucieczka przed złem, wal- } \\
\text { ką i zabójcami. Tylko nielicznym udawało się wydostać. Ja } \\
\text { akurat miałem to szczęście. (20) }\end{array}$ \\
\hline
\end{tabular}

W analizowanych pracach do najczęstszych przyczyn stawania się uchodźcą należy ucieczka przed wojną i przed szeroko rozumianym złem. Wojną, ponieważ działania militarne nie tylko dzieją się w krajach Bliskiego Wschodu, lecz prowadzone są także na terenie Kazachstanu czy Ukrainy:

Ukraina jest moją ojczyzną i zawsze wspaniale żyłam w otoczeniu ukraińskich sklepów, ludzi, mieszkań. Niestety, na nasze ziemie przyszły wojska rosyjskie i wszystko co stanęło im po drodze niszczyli. Zniszczyli mi cały mój dobytek — dom, ogród, hodowlę kurczaków. Ja mieszkałam tylko z ojcem, który walczył na wojnie i on kazał mi uciec do najbliższego kraju. W moim przypadku była to Polska. (27)

Z wojną wiąże się trudna sytuacja finansowo-gospodarcza, spowodowana działaniami zbrojnymi. W konsekwencji więzi rodzinne bohaterów wypracowań rozpadają się, kierują nimi kłótnie i konflikty interesów. Zdarza się również, że stan gospodarki państw powoduje dramat uchodźstwa:

Gospodarka w moim kraju nie jest w najlepszym stanie. Mój syn mieszka niedaleko stąd i to dzięki niemu mogłem się wyprowadzić. Nie sądzę, że „wyprowadzić” to dobre słowo. Tak naprawdę była to ucieczka. Ucieczka przed złem, walką i zabójcami. Tylko nielicznym udawało się wydostać. Ja akurat miałem to szczęście. (20)

${ }^{19}$ Wskazane numery są przypisane danemu uczniowi. Nie mają one związku z numerami przy nazwiskach w dzienniku lekcyjnym Librus. 
Drugą najliczniejszą grupę przyczyn stanowi ucieczka przed szeroko rozumianym złem, która wiąże się z krzywdą psychiczną i fizyczną mieszkańców, rozpadem rodziny, atakami terrorystycznymi czy życiem w państwie totalitarnym. W analizowanych pracach głęboko przemyślanym przez jedną z uczennic powodem stawania się uchodźcą jest łamanie praw kobiet $\mathrm{i}$ ich życie w męskiej niewoli:

W końcu postanowiłam walczyć o równouprawnienie. Przyłączyłam się do grupy walczącej o to samo. Na początku nie robiłam nic, zadowolona, że zrobiłam coś dla tej sprawy. Później zdałam sobie sprawę, że moje wstąpienie do grupy nic nie pomogło i niczego nie zmieniło. Wtedy zaczęłam działać bardzo intensywnie. Nie mogło się to dla mnie dobrze skończyć. Zamknięto mnie w więzieniu dla kobiet na dziesięć lat — ciemnowłosa opowiedziała o tym z niemałym smutkiem. (20)

Fanatyzm religijny krajów islamskich powoduje, że bohaterowie opowiadań są ofiarami prześladowań za wyznawanie chrześcijaństwa:

Pewnego dnia usłyszałem strzały i krzyki. Wyjrzałem przez okno i ujrzałam dym oraz ogien, potem przyjechały ciężarówki samochody z czarnymi flagami. Kazali mi udowodnić swoją wiarę, bo inaczej mnie zabiją. Powiedziałem, że muszę się przygotować. Wyskoczyłem przez okno i biegłem. (7)

Ad c) Co tracą uchodźcy?

Uchodźcy tracą:

- rodzinę,

— przyjaźń, honor,

— ojczyznę, bezpieczeństwo,

— dobrobyt, spokój.

W analizowanych opowiadaniach najczęściej bohaterowie w wyniku ucieczki tracą to, co dla nich najważniejsze - rodzinę i przyjaciół. Tę krzywdę odczuwają bohaterowie największej liczby prac (6), co obrazuje fragment z pracy nr 9:

Nie było to łatwe. Kiedy moja rodzina została... zabita, uznałem, że nie mogę dłużej zwlekać. To była moja jedyna szansa. Udałem się do znajomego, który miał swoją własną łódź. On także zamierzał uciec. Zebraliśmy zapasy i ruszyliśmy przed siebie - zaczął opowiadać mężczyzna. Podróż trwała miesiąc. Zapasy starczyły nam tylko na trzy tygodnie, więc jeden tydzień musieliśmy przeżyć na prawie samej wodzie. Na szczęście udało nam się. (9)

Drugą największą stratą uciekinierów jest ojczyzna, a co za tym idzie bezpieczeństwo, spokój, dobrobyt:

- I jak panu tu się mieszka?

— Raczej dobrze tylko tęsknię za moją ojczyzną, ale musiałem się tu przenieść z moją rodziną by uratować życie moje i ich. (17)

Ad d) Jakimi cechami charakteryzuje się uchodźca?

Według autorów opowiadań uchodźca jest:

— pracowity, zdeterminowany,

- samodzielny,

— rodzinny,

- smutny, 
— mający swoje zainteresowania,

— zagubiony, krzykliwy,

— tchórzliwy,

- szanujący swoje korzenie,

- wyniosły.

Konstrukcja psychologiczna bohaterów jest skomplikowana. Dominującą cechą uchodźców jest pracowitość i determinacja:

Ludzie mnie nie znają. Myślą, że jestem zwykłym człowiekiem, co żebrze pieniądze na ulicy. Życie nie jest bez przeszkód, często upadasz. Na szczęście dzięki temu upadkowi możesz się potem podnieść i z dumą pokazywać wszystkim. (20)

Dalej wyróżnić można samodzielność oraz szacunek do rodziny. W negatywnym świetle zostały przedstawione tchórzostwo i wyniosłość uciekinierów.

\section{Ad e) Jakie trudności napotykają uchodźcy?}

\begin{tabular}{|c|c|}
\hline Trudności uchodźców & Fragment opowiadania, numer pracy \\
\hline $\begin{array}{l}\text { wędrówka: długa dro- } \\
\text { ga, głód, pragnienie, } \\
\text { lęk przed napotkanym } \\
\text { człowiekiem, niewy- } \\
\text { goda, samodzielność, } \\
\text { hałas, atmosfera wojny, } \\
\text { niesprzyjająca pogoda }\end{array}$ & $\begin{array}{l}\text { Z Aleppo do Wrocławia jest ponad } 3 \text { tysiące kilometrów, a moja ro- } \\
\text { dzina musiała pokonać te kilometry nielegalnymi łodziami lub pie- } \\
\text { chotą. Kiedy podwiózł nas samochodów dla uchodźców do Prievidzy } \\
\text { w Słowacji, skończyło nam się jedzenie, a przecież zostało nam jesz- } \\
\text { cze } 338 \text { kilometrów do przejścia, przez } 69 \text { godzin drogi. Wytrzyma- } \\
\text { liśmy jeszcze } 20 \text { kilometrów i zobaczyliśmy stację benzynową, lecz } \\
\text { nie mieliśmy ani pieniędzy, ani wstępu na teren stacji. Dla rodziny } \\
\text { postanowiłem zaryzykować życiem i poprosiłem mężczyznę, który } \\
\text { akurat stanął na tej stacji, aby kupił nam kilka butelek wody oraz tro- } \\
\text { chę chleba. Czekałem już tylko na wysunięcie ruchu przeciwko mnie, } \\
\text { a tymczasem mężczyzna spytał się „Woda ma być niegazowana?”. } \\
\text { Moje poświęcenie opłaciło się mojej rodzinie. Każdy z nas dostał po } \\
15 \text { butelek wody i } 15 \text { kanapek. To był jak dar z nieba. (1) } \\
\text { Podróż była bardzo długa. W końcu dotarliśmy na miejsce. Gdy wsze- } \\
\text { dłem do środka zobaczyłem kilka osób. Miało dojechać jeszcze więcej. } \\
\text { Mieszkaliśmy tam dłuższy czas. Żołnierze dostarczali nam niezbędne } \\
\text { środki do życia. Pewnego dnia powiedzieli, że mamy sobie radzić sami. } \\
\text { Młodzież, która była tam razem ze mną wykradała się nocą i przynosiła } \\
\text { jedzenie. Po kilku dniach nie dało się wytrzymać. Odgłosy wystrzałów } \\
\text { były coraz głósniejsze i przerażające. Postanowiłem uciec z tego schro- } \\
\text { nu. Przygotowałem się do podróży. Spakowałem do plecaka wszystkie } \\
\text { potrzebne rzeczy. Ruszyłem nocą. Było chłodno i przyjemnie. Nie było } \\
\text { słychać żadnych wystrzałów. Szedłem skradając się. Zbliżałem się do } \\
\text { ruin domów. Pomiędzy nimi znalazłem jeszcze niezużytą broń. Zabra- } \\
\text { łem ją na wszelki wypadek. Słońce powoli zaczęło wschodzić. Postano- } \\
\text { wiłem, że zrobię postój w ruinach budynków. Położyłem się i zasnąłem. } \\
\text { Gdy się obudziłem, było południe. Ruszyłem dalej. (12) } \\
\text { Pewien znajomy miał kolegę przemytnika - wykorzystałem to. Od- } \\
\text { dałem mu cały dobytek, a on mnie bezpiecznie przewiózł. Tam dosta- } \\
\text { łem azyl w Polsce i się jakoś poukładało. ( } 7 \text { ) }\end{array}$ \\
\hline
\end{tabular}




\begin{tabular}{|l|l|}
\hline zostanie w ojczyźnie & $\begin{array}{l}\text { Na początku jest trudno. Odejście trzeba zaplanować dużo wcześniej } \\
\text { i odpowiednio się do niego przygotować. Już na początku gimnazjum } \\
\text { zaplanowałem ucieczkę i zacząłem dorabiać. Gdy byłem za młody na } \\
\text { pracę, grałem na gitarze w różnych miejscach, potem zacząłem pra- } \\
\text { cować. Odkładałem sporo pieniędzy nawet z tych, które dostawałem } \\
\text { w prezencie na urodziny czy inną okazję. Gdy nadszedł czas, odliczy- } \\
\text { łem odpowiednią kwotę na jakieś miejsce zamieszkania, a za resztę } \\
\text { kupowałem bilety. Czasem dawałem koncerty, aby nie sprowadzić się } \\
\text { do całkowitego bankructwa. (18) }\end{array}$ \\
\hline $\begin{array}{l}\text { Nie było to łatwe. Kiedy moja rodzina została... zabita, uznałem, że } \\
\text { nie mogę dłużej zwlekać. To była moja jedyna szansa. Udałem się do } \\
\text { znajomego, który miał swoją własną łódź. On także zamierzał uciec. } \\
\text { Zebraliśmy zapasy i ruszyliśmy przed siebie - zaczął opowiadać } \\
\text { mężczyzna. - Podróż trwała miesiąc. Zapasy starczyły nam tylko na } \\
\text { trzy tygodnie, więc jeden tydzień musieliśmy przeżyć na prawie samej } \\
\text { wodzie. Na szczęście udało nam się. (21) }\end{array}$ \\
\hline $\begin{array}{l}\text { Gdy trafiliśmy do naszych przyjaciół, walka rozpętała się na dobre. } \\
\text { Wraz z moim kolegą ruszyliśmy do boju. Bitwa była zacięta, kolej- } \\
\text { ni żołnierze padali. Nasi i żołnierze wroga. W pewnym momencie } \\
\text { ściana pyłu oddzieliła mnie od reszty walczących. Kiedy rozniosła } \\
\text { się w powietrzu ujrzałem mojego przyjaciela padającego na ziemię. } \\
\text { Wyglądał na nieżywego. W tamtym momencie spanikowałem. Taki } \\
\text { sam los mógł spotkać też mnie. Położyłem się na wyschniętej ziemi } \\
\text { i zacząłem się czołgać, przystając co jakiś czas. (11) }\end{array}$ \\
\hline emocje
\end{tabular}

W analizowanych opowiadaniach wskazać można cztery grupy trudności, z którymi borykają się uchodźcy. Pierwsza dotyczy samej wędrówki (długa droga, głód, pragnienie, lęk przed napotkanym człowiekiem, niewygoda, hałas, trudne warunki pogodowe).

Drugą grupą są trudności związane z pozostaniem na miejscu, w kraju ojczystym. Wówczas bohaterowie czują lęk przed tak zwanym państwem islamskim, więzieniem.

Trzecia grupa problemów dotyczy w dużej mierze rodziny. Uchodźcy zmagają się z licznymi chorobami, brakiem lekarstw.

Dla uciekinierów trudne bywają ich emocje. Nie mogą poradzić sobie z tęsknotą za ojczyzną, cierpią z powodu straty najbliższych, w ich świadomości powracają obrazy zgrozy i dramatu z miejsca ucieczki.

\section{Ad f) Jakie propozycje pomocy słyszy uchodźca?}

\begin{tabular}{|l|l|}
\hline \multicolumn{1}{|c|}{ Propozycje pomocy } & \multicolumn{1}{c|}{ Fragment opowiadania, numer pracy } \\
\hline wysłuchanie & - Byłem uciekinierem. \\
& - Dlaczego? - spytałam. \\
& - To długa historia. Na pewno nie będziesz chciała tego słuchać. \\
& - Bardzo chętnie posłucham - odpowiedziałam. (12) \\
& oraz prace nr: $17,19,20,22,24,27$ \\
\hline
\end{tabular}




\begin{tabular}{|c|c|}
\hline doraźna pomoc & $\begin{array}{l}\text { Zdecydowanie, uratował nasze życie. Gdy byliśmy już w Polsce, } \\
\text { dokładniej w Strzelnie przechodziliśmy przez tory, stoczyłem się } \\
\text { z wielkiej góry i moja ręka nadziała się na ostry patyk na dole. } \\
\text { Została nam wtedy tylko jedna woda na nas trojga. Pozostało nam } \\
8 \text { godzin chodzenia i też tyle czasu musiałem pilnować ręki, by nie } \\
\text { wdało się zakażenie. Po upływie tych godzin dotarliśmy do miejsca. } \\
\text { Potem znaleźliśmy opuszczony, mały domek niedaleko szkoły i in- } \\
\text { nych domów, w którym zamieszkamy. (1) }\end{array}$ \\
\hline przyjęcie do domu & $\begin{array}{l}\text { Wchodząc do miasta, spotkaliśmy kobietę. Widząc, że jesteśmy } \\
\text { zmęczeni, zaprosiła nas do siebie. Właśnie będąc u (wtedy jesz- } \\
\text { cze) pani Marii, poznałem miłość mojego życia - ukochaną Kla- } \\
\text { rę. Pobraliśmy się. Niedawno pani Maria zachorowała. Moja żona } \\
\text { jest zrozpaczona... A ja? Co mogę zrobić? Nic. Ja jestem po prostu } \\
\text { uciekinierem, który się zakochał... - skończył mówić. Patrzył się } \\
\text { przed siebie. (5) }\end{array}$ \\
\hline $\begin{array}{l}\text { koleżeństwo, zrozumie- } \\
\text { nie }\end{array}$ & $\begin{array}{l}\text { — Och... skąd? - zapytałem się ponownie, lecz tym razem bar- } \\
\text { dziej niepewnie. } \\
\text { - Z Syrii — powiedział cicho nieznajomy. — Pewnie uważasz } \\
\text { mnie za dziwaka, bo uciekłem z kraju... } \\
\text { — Nie, wręcz przeciwnie, rozumiem cię - wypowiedziałem, pró- } \\
\text { bując pocieszyć mężczyznę. (9) }\end{array}$ \\
\hline rady & $\begin{array}{l}\text { Czemu niby? Jakoś trzeba było sobie radzić, a poza tym to był tylko } \\
\text { rok, bo w drugiej klasie byłem już pełnoletni. Może nie było to do- } \\
\text { bre, ale nie miałem innego wyjścia. } \\
\text { Mogłeś wyjechać dopiero na studia lub przemieszkać te trzy lata } \\
\text { u jakiegoś członka rodziny. } \\
\text { Chciałem jak najszybciej zacząć swoje życie. (18) }\end{array}$ \\
\hline $\begin{array}{l}\text { odprowadzenie do komi- } \\
\text { sariatu policji }\end{array}$ & $\begin{array}{l}\text { — Niech Pan odejdzie ode mnie! Śpieszy mi się! [...] } \\
\text { — Dobrze. Oprowadzę Pana na komisariat. (14) }\end{array}$ \\
\hline
\end{tabular}

Kolejne kryterium badawcze pozwala wykazać, w jaki sposób bohaterowie opowiadań pomagają uchodźcom. W znaczącej większości nie znajdują oni rozwiązania na problemy, o których słyszą od uciekinierów. Przeważającą postawą wobec nich jest po prostu wysłuchanie opowieści o ich życiu, bohaterowie zatrzymują się na przystanku tramwajowym i chcą, by napotkani opowiedzieli im o swojej niedoli. W pojedynczych przypadkach otrzymują pożywienie, mogą liczyć na koleżeństwo czy radę. Jednak nie zawsze, na przykład w jednym z wypracowań uchodźca zostaje odprowadzony do komisariatu policji. 


\section{Ad g) Jak układa się/ułożyło się w Polsce uchodźcom?}

\begin{tabular}{|c|c|}
\hline $\begin{array}{l}\text { Jak uchodźcom układa } \\
\text { się/ułożyło się życie } \\
\text { w Polsce? }\end{array}$ & Fragment opowiadania, numer pracy \\
\hline zdobywają pracę & $\begin{array}{l}\text { Razem z moją żoną zaczęliśmy pracować w ogrodzie dosyć boga- } \\
\text { tego człowieka - tak zarabialiśmy. Ale dało się żyć, bo mieliśmy } \\
\text { chleb, mieliśmy wodę, a nasz syn był przez nas uczony w domu. Po } \\
\text { roku nasz „domek” zaopatrzyliśmy w większe meble, lepsze drzwi } \\
\text { i okna przez ręczniki, lodówkę, palnik i umywalkę, a syna zapisali- } \\
\text { śmy do szkoły. I właśnie tak rozpoczęliśmy nowe życie. (1) }\end{array}$ \\
\hline zakochują się & $\begin{array}{l}\text { Właśnie będąc u (wtedy jeszcze) pani Marii, poznałem miłość moje- } \\
\text { go życia - ukochaną Klarę. Pobraliśmy się. Niedawno pani Maria } \\
\text { zachorowała. Moja żona jest zrozpaczona... A ja? Co mogę zro- } \\
\text { bić? Nic. Ja jestem po prostu uciekinierem, który się zakochał... } \\
\text { — skończył mówić. Patrzył się przed siebie. (5) }\end{array}$ \\
\hline $\begin{array}{l}\text { żyją w gorszych warun- } \\
\text { kach, wykorzystani przez } \\
\text { przemytników }\end{array}$ & $\begin{array}{l}\text { Pewien znajomy miał kolegę przemytnika - wykorzystałem to. } \\
\text { Oddałem mu cały dobytek, a on mnie bezpiecznie przewiózł. Tam } \\
\text { dostałem azyl w Polsce i się jakoś poukładało. (7) }\end{array}$ \\
\hline $\begin{array}{l}\text { są pozytywnie nastawieni } \\
\text { mimo trudności finanso- } \\
\text { wych }\end{array}$ & $\begin{array}{l}\text { — Potem dostaliśmy się tutaj, do Polski — wymówił te słowa, cie- } \\
\text { kawie akcentując. } \\
\text { — Mieszkacie razem? - spytałem. } \\
\text { — Tak, na razie tak - odpowiedział. } \\
\text { — Mam nadzieję, że wszystko wam się układa. } \\
\text { — Na razie nie narzekamy - powiedział, śmiejąc się, mężczyzna. } \\
\text { (8) }\end{array}$ \\
\hline $\begin{array}{l}\text { mają poczucie winy, bo } \\
\text { zostawili ojczyznę }\end{array}$ & $\begin{array}{l}\text { Coś we mnie pękło. Nie zważając na krzyki innych, zdezerterowa- } \\
\text { łem. Po prostu uciekłem. Następnie udałem się do pobliskiego portu } \\
\text { i wróciłem do Polski. Sam. Bez mojego oddziału. Z narastającym } \\
\text { mnie poczuciem winy. Do dziś nachodzi mnie nurtujące pytanie. } \\
\text { Czy to było tchórzostwo? } \\
\text { Nie wiem - odparłam po chwili zastanowienia. - Każdy ma kie- } \\
\text { dyś czas słabości. (11) }\end{array}$ \\
\hline tęsknią za ojczyzną & $\begin{array}{l}\text { - I jak panu tu się mieszka? } \\
\text { — Raczej dobrze, tylko tęsknię za moją ojczyzną, ale musiałem się } \\
\text { tu przenieść z moją rodziną, by uratować życie moje i ich. (9) }\end{array}$ \\
\hline idą na studia & $\begin{array}{l}\text { Uczyłem się pilnie, dzięki czemu z dostaniem się na studia nie było } \\
\text { problemu. Teraz jestem na pierwszym roku psychologii. Życie wie- } \\
\text { le mnie nauczyło i teraz mam zamiar swoim doświadczeniem po- } \\
\text { magać innym. (11) }\end{array}$ \\
\hline
\end{tabular}


skutecznie uczą się języka polskiego
Ukraina jest moją ojczyzna i zawsze wspaniale żyłam w otoczeniu ukraińskich sklepów, ludzi, mieszkań. Niestety, na nasze ziemie przyszły wojska rosyjskie i wszystko, co stanęło im po drodze, niszczyli. Zniszczyli mi cały mój dobytek — dom, ogród, hodowlę kurczaków. Ja mieszkałam tylko z ojcem, który walczył na wojnie i on kazał mi uciec do najbliższego kraju. W moim przypadku była to Polska. Akurat dwa lata temu uczyłam się języka polskiego, więc mogę się komunikować z ludźmi. Nie chciałam się żegnać z Ukrainą ani na chwilę, lecz ta okropna sytuacja mnie zmusiła. Czuję się jak najgorszy uciekinier i jest mi z tym źle. (3)

Powyższe zestawienie pokazuje, jak ułożyło się życie uchodźców w Polsce. Z prac szóstoklasistów wynika, że jest ono skomplikowane, pełne wyrzeczeń i tęsknoty za ojczyzną. Uchodźcy wprawdzie żyją w gorszych warunkach niż w ojczystym kraju, ale także dzięki swojej odwadze i determinacji zdobywają pracę, zaczynają studia, zakochują się oraz świetnie radzą sobie z językiem polskim.

\section{Wnioski}

W analizowanych wypracowaniach uczniowskich:

— uczniowie traktują synonimicznie pojęcia imigranci, uchodźcy, uciekinierzy, wędrowcy;

— dostrzegają problemy i złożoność sytuacji uchodźców;

— bohaterowie są zazwyczaj mieszkańcami Syrii;

— najczęstszym powodem uchodźstwa jest wojna;

— głównym problemem uchodźców jest utrata najbliższych;

— rozmówcy traktują się z życzliwością, są sobą zainteresowani;

— życie w Polsce układa się im pomyślnie.

Jeden z uczniów napisał:

Udałem się do znajomego, który miał swoją własną łódź. On także zamierzał uciec. Zebraliśmy zapasy i ruszyliśmy przed siebie — zaczął opowiadać mężczyzna. — Podróż trwała miesiąc. Zapasy starczyły nam tylko na trzy tygodnie, więc jeden tydzień musieliśmy przeżyć na prawie samej wodzie. Na szczęście udało nam się. (9)

W uczniowskich pracach uchodźcom „udało się”, ale pozostaje wciąż otwarte pytanie, jak poradzą sobie w realnym życiu.

\section{Bibliografia}

Bohosiewicz M., Kornacki P., Jurewicz J., Marek A., Kuspys P., Halik T., Czerniejewska I., Imigranci w mojej klasie, Warszawa 2011.

CBOS, Stosunek Polaków do przyjmowania uchodźców, Komunikat z Badań 2017, nr 1.

Cieliczko P., Kuciński P., Literackie portrety innego, t. 3, Warszawa 2008. 
Czerniejewski M., Kubiak I., Malczewska M., Szczepanik W., Uchodźcy. Materiat pomocniczy dla prowadzacych zajęcia na temat uchodźców, Poznań 2011.

Dąbrowski M., Swój/Obcy/Inny. Z problemów interferencji i komunikacji międzykulturowej, Izabelin 2001.

Dudzik M., Badania eksperymentalne nad ksztatceniem słownictwa i frazeologii w szkole (Próba wykorzystania ich $w$ dydaktyce uniwersyteckiej), „Kształcenie Językowe w Szkole” 1, Wrocław 1983.

Dudzik M., Bogacenie słownictwa wokót hasła: człowiek i środowisko, „Kształcenie Językowe w Szkole" 3, Wrocław 1986.

Gosk H., O czym opowiada Inny/Obcy, „Horyzonty Polonistyki” 2006, nr 6, s. 11-12.

Jacyno M., Iluzje codzienności. O teorii socjologicznej Pierre a Bourdieu, Warszawa 1997.

Kupisiewicz C., Podstawy dydaktyki, Warszawa 1982.

Labocha J., Dyskurs jako proces przekazywania wiedzy, [w:] Dyskurs edukacyjny, red. T. Rittel, Kraków 1996.

Levinas E., Etyka i nieskończony, przeł. B. Opolska-Kokoszka, Kraków 1994 („,Teksty Filozoficzne").

Levinas E., Trudna wolność, przeł. A. Kuryś, Gdynia 1991.

Łobocki M., Metodologia badań pedagogicznych, Warszawa 1982.

Nagajowa M., ABC metodyki języka polskiego dla początkujących nauczycieli, wyd. 2, Warszawa 1995.

Nowak E., Stworzyć tekst. Uczniowska kompetencja tekstotwórcza w edukacji polonistycznej, Kraków 2014.

Pilch T., Bauman T., Radźko A., Zasady badań pedagogicznych, Warszawa 1995.

Skudrzykowa A., Warchala J., Dyskurs edukacyjny a kompetencja interakcyjna, „Studia Pragmalingwistyczne" 2002,nr 3.

Słownik terminów literackich, red. J. Sławiński, wyd. 2, Wrocław 1988.

Waldenfels B., Podstawowe motywy fenomenologii obcego, przel. J. Sidorek, Warszawa 2009.

Waldenfels B., Topografia obcego. Studia z fenomenologii obcego, przeł. J. Sidorek, Warszawa 2002.

Wokół edukacji polonistycznej w szkole. Teoria i praktyka, red. M. Karwatowska, L. Tymiakin, Lublin 2016.

Zaczyński W., Praca badawcza nauczyciela, wyd. 4, Warszawa 1995.

Zamojska E., Inny jako Obcy. Imigranci w polskim dyskursie publicznym i edukacyjnym, „Studia Edukacyjne" 2013, nr 28, s. 191.

Zrozumieć innych, czyli jak uczyć o uchodźcach, red. K. Koszewska, Warszawa 2011.

https://amnesty.org.pl/wp-content/uploads/2016/04/Konwencja_Dotyczaca_Uchodzcow.pdf [dostęp: 13.07.2017].

http://uchodzcy.info/infos/stosunek-polakow-do-uchodzcow/ [dostęp: 13.07.2017]. 